\title{
Spectrophotometric Determination of Lacosamide in Bulk Drug and Oral Dosage Formulation
}

\author{
Vikramsinh R. Chauhan ${ }^{1}$, Deepshikha Sharma ${ }^{1}$, Kartik B. Vyas ${ }^{*}$ \\ ${ }^{1}$ Department of Chemistry, Sheth L.H. Science College, (Scholars of Gujarat University, Ahmedabad) \\ Mansa, India \\ ${ }^{2 *}$ Department of Chemistry, Sheth L.H. Science College, Mansa, Gujarat University, Ahmedabad, India.
}

\begin{abstract}
A simple, rapid, cost effective and extractive UV-Vis spectrophotometric method has been developed for the determination of Lacosamide (LA) in bulk drug and pharmaceutical formulation. It was based on UV-Vis spectrophotometric measurements in which the drug reacts chromogenic reagent 4-Chloro-7-nitrobenzo-2-oxa-1,3diazole in alkaline medium and give stable pale yellow colored complex which exhibits absorption maximum at 420 $\mathrm{nm}$. Beer's law was obeyed in the concentration range of $0.04-40 \mu \mathrm{g} / \mathrm{ml}$. This method was tested and validated for various parameters according to ICH guidelines. The proposed method was successfully applied for the determination of LA in oral formulation. The results demonstrated that the procedure is accurate, precise and reproducible (relative standard deviation $<2 \%$ ). As it is simple, cheap and less time consuming, it can be suitably applied for the estimation of LA in dosage forms in quality control labs.
\end{abstract}

Keywords : Lacosamide, ICH, Spectrophotometric, Antiepileptic drugs

\section{INTRODUCTION}

Epilepsy is a chronic non contagious disease of the brain that affects around 50 million people worldwide [1]. It is characterized by recurrent seizures, loss of consciousness and control of bowel or bladder function. Seizures are the brief episode of involuntary movement which involve a specific part of body or whole body. It occurs due to excessive electrical discharges in a group of brain cells. According to conventional definition these kinds of two or more than two unprovoked seizures called epilepsy. Loss of awareness, distribution of movement and sensation are temporary symptoms of epilepsy on the other hand anxiety and depression is the major symptoms of the disease. Latest statistical reports have shown that approximately $0.5-1.0 \%$ of general population. Epilepsy is not a divergent syndrome; it leads impermanent dysfunction of one or more brain areas by repetitive continuous incidence of abnormal bioelectrical management of a large number of neurons.

Antiepileptic drugs (ADE) are approved by various drug regulatory bodies for the treatment of epilepsy and other psychiatric disorders.[2] Drug come under this class categorise in different generation; first generation AEDs include carbamazapine, phenobarbital and phenytoin second generation AEDs are lamotrigine, pregablin and topiramate; and in thired generation lacosamide, perampanel, eslicarbazepine acetate, rufinamide etc.

Lacosamide is R-enantiomer of 2- acetamido- $\mathrm{N}$ benzyl-3-methoxypropionamide and has a functionalized amino acid [3] which contributes for epilepsy treatment further has been evaluated for anticonvulsant properties.[4,5] Lacosamide is a white to yellow crystalline powder. Due to its highly polar nature it is soluble in phosphate buffer saline and has 
almost $100 \%$ bioavalibility after oral administration. It has a half life of $13 \mathrm{~h}$ and 2-4 days are needed to achieve steady state.[6] Lacosamide enhance slow inactivation phase of sodium channels without affecting fast inactivation. It does not bind gammaaminobutyric acidergic or glutamatergic targets and does not modulate calcium or potassium currents.

The therapeutic concentration rang of lacosamide is 5-15 $\mu \mathrm{g} / \mathrm{mL}$. [7]The most common side effect of the drug includes headache, nausea, tremors, and dizziness and vomiting, consequently it has been used in a combination with other ADEs for the treatment. [8] In case of ADEs the therapeutic drug monitoring is significant. To minimize the adverse effect and to prevent the seizures desire concentration level of drug should be maintained. [9]

Furthermore, a reliable, simple and sensitive method for the determination of lacosamide drug level should be necessary for therapeutic drug monitoring. The desirable method should be able to analyze the biological samples. There are various method have been reported for the determination of lacosamide from drug product and biological samples. These methods are mainly based on liquid chromatography with the help of a range of detectors such as UV detector [10, 11], mass and tandem mass spectrometry.[12,13] Gas chromatography has been used for the determination of lacosamide from various biological samples along with their related impurities.[14,15] All these chromatographic techniques are selective and sensitive although these techniques require high skilled analyst, expensive solvent system and highly sophisticated equipments and infrastructure. Hence it requires developing easy, robust and cost effective detection and determination method for lacosamide. As per our knowledge very few reports has been publish based on detection and determination of lacosamide by spectroscopy techniques. In this work we develop selective and sensitive colorimetric method for the qualitative and quantative determination of lacosamide form different formulations.

\section{EXPERIMENTAL}

\section{Chemicals and reagents:}

Lacosamide (LA)(Gift sample from Alembic Research centre, Vadodara), phosphate buffer $\mathrm{pH}$ 7.2, 4Chloro-7-nitrobenzo-2- oxa-1,3-diazole (NBD) (Merck, Mumbai, India), hydrochloric acid (HCl) ((Sd fine Chem Ltd., Mumbai, India)

\section{Instrument}

JASCO V-570 UV-Visisble scanning spectrophotometer equipped with $1 \mathrm{~cm}$ matched quartz cell was used.

\section{Solution Preparations}

\section{Preparation of phosphate buffer $\mathrm{pH}$ 7.2:}

$17.85 \mathrm{~g}$ of $\mathrm{Na}_{2} \mathrm{HPO}_{4} \& \mathrm{H}_{2} \mathrm{O}, 4.61 \mathrm{~g}$ of $\mathrm{NaH}_{2} \mathrm{PO}_{4} \mathrm{H}_{2} \mathrm{O}$ in $800 \mathrm{ml}$ distilled water adjust suitable $\mathrm{pH}$ using $\mathrm{HCl}$ and dilute up to $1000 \mathrm{ml}$.

\section{NBD-Cl (1\%):}

One gram of NBD-Cl was transfer in $100 \mathrm{ml}$ volumetric flask than dissolved in methanol and diluted up to mark by same solvent.

\section{Preparation of the standard drug solution Standard stock solution $(1 \mathrm{mg} / \mathrm{ml})$ :}

$100 \mathrm{mg}$ Lacosamide (LA) accurately weighed and transferred into $100 \mathrm{ml}$ volumetric flask, dissolved and diluted to $100 \mathrm{ml}$ with methanol.

\section{Working standard solution $(1 \mu \mathrm{g} / \mathrm{ml})$ :}


Accurately $1 \mathrm{ml}$ of standard stock solution was transferred in to $100 \mathrm{ml}$ volumetric flask and then diluted up to mark by phosphate buffer pH 7.2.

\section{Analytical Procedure:}

In $10 \mathrm{ml}$ volumetric flask, required volume of LA working standard solution has transferred and $1.0 \mathrm{ml}$ of $1 \%$ NBD were added mixed it well and heated on a water bath at $40^{\circ} \mathrm{C}$ for 15 minutes. The flask was cooled at room temperature then $0.2 \mathrm{ml}$ of $\mathrm{HCl}$ was added in to it and diluted up to mark with methanol. The absorbance of solution was measured at $420 \mathrm{~nm}$ against blank treated with similarly except without drug.

The method after its application for the determination of LA from bulk drug and pharmaceutical formulation was subjected to statistical validation.

\section{Analytical Validation}

Processes that confirm the analytical procedure/method is suitable for specific compound is called method validation [16].

\section{Calibration curve/ Linearity:}

Into series of $10 \mathrm{ml}$ volumetric flasks, different volume $(0.2-4.0 \mathrm{ml})$ of LA working standard solutions have transferred and $0.8 \mathrm{ml}$ of $1 \% \mathrm{NBD}$ were added mixed it well and heated on a water bath at $40^{\circ} \mathrm{C}$ for 15 minutes. The flasks were cooled at room temperature then $0.2 \mathrm{ml}$ of $\mathrm{HCl}$ was added in each flask and diluted up to mark with methanol. The absorbance of each solution was measured at $420 \mathrm{~nm}$ against blank treated with similarly except without drug. The methodology was adopted in triplicates. A calibration curve was plotted between mean absorbance vs. concentration of drug and linear regression equation was computed.

\section{Limit of detection (LOD)}

The lowest concentration of analyte in sample which can be detected by cannot be quantified under the same experimental condition. Limit of detection was calculated from calibration curve using following equation.

$$
\mathrm{LOD}=3.3 \sigma / \mathrm{S}
$$

Where $\sigma=$ S.D of $y$-intercept of calibration curves $\mathrm{S}=$ Mean of slope of calibration curve

\section{Limit of quantification (LOQ)}

The lowest concentration of analyte from sample which can precisely and accurately measured under same experimental condition. Limit of quantification was calculated from calibration curve using following equation.

$$
\mathrm{LOQ}=10 \sigma / \mathrm{S}
$$

Where $\sigma=$ S.D of y-intercept of calibration curves $\mathrm{S}=$ Mean of slope of calibration curve

\section{Precision}

Precision is the measure of either the degree of reproducibility or repeatability of the analytical method. It is expressed in terms of standard deviation or relative standard deviation (co-efficient of variation).

\section{Intraday and interday precision}

Intraday precision study was determined at three different concentrations of calibration curve for three times in the same day. Interday precision was determine by analyzing drug at three different days.

\section{Accuracy}

Accuracy of the analytical method is closeness of the experimental result with the true value. Accuracy was determined by spiking the known amount of standard solution into the pre-analyzed sample solution at three levels (80, 100 and 120\%). 


\section{Analysis of marketed formulation}

Twenty tablets were accurately weighed and finely powdered. Powder equivalent to $100 \mathrm{mg}$ LA was transferred into $100 \mathrm{~mL}$ volumetric flask. Methanol $(50 \mathrm{~mL}$ ) was added and sonicated for $15 \mathrm{~min}$, filtered using Whatman filter paper no.41 and volume was made upto the mark with phosphate buffer $\mathrm{pH}$ 7.2. Aliquot $(1 \mathrm{~mL})$ was transferred into a $100 \mathrm{~mL}$ volumetric flask and diluted with with same buffer solution. The solution $(1 \mathrm{~mL})$ was transferred into a $10 \mathrm{~mL}$ volumetric flask and analysed as described under standard solution method. The absorbance of colored solution was measured at $420.0 \mathrm{~nm}$ against reagent blank.

\section{RESULTS AND DISCUSSION}

\section{Method development:}

\section{Optimization of $\mathrm{pH}$}

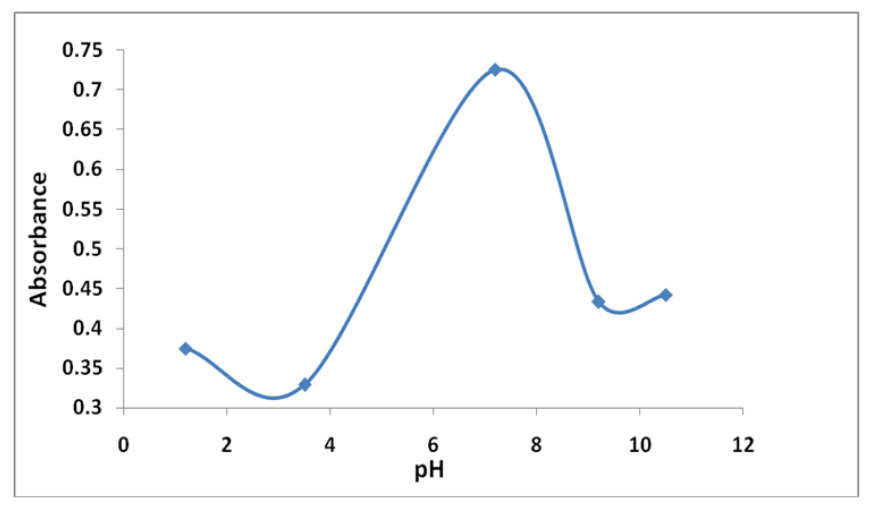

Figure 1 : Optimization of $\mathrm{pH}$

$\mathrm{pH}$ of reaction environment is an important parameter for the reaction mechanism of complex formation between drug molecule and ligand. It is also influence on the specificity of develop method for drug detection and determination. The results obtained from this study clearly indicates that phosphate buffer $\mathrm{pH} 7.2$ provide most favourable condition for complexation and distinctive color development.

\section{Optimization of volume of $1 \% \mathrm{NBD}-\mathrm{Cl}$}

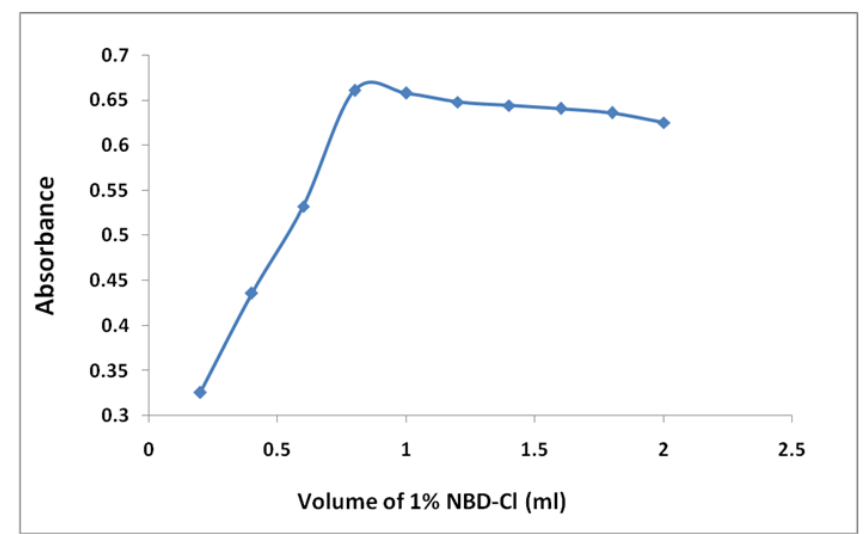

Figure 2 : Optimization of NBD-Cl

$\mathrm{NBD}-\mathrm{Cl}$ is the key regent in this color development chemistry. In this study we optimize the volume of $1 \%$ NBD-Cl solution used for intense color development. Here we add 0.2 to $2.0 \mathrm{ml}$ of $1 \% \mathrm{NBD}-\mathrm{Cl}$ solution in $0.2 \mathrm{ml}(1 \mu \mathrm{g} / \mathrm{ml})$ as per above discussed procedure. Results of this study reveal that $0.8 \mathrm{ml}$ of $1 \% \mathrm{NBD}-\mathrm{Cl}$ is requiring getting intense color development with maximum absorbance. Above $1.0 \mathrm{ml}$ the absorbance of developed complex will remain almost constant.

\section{Optimization of Reaction temperature}

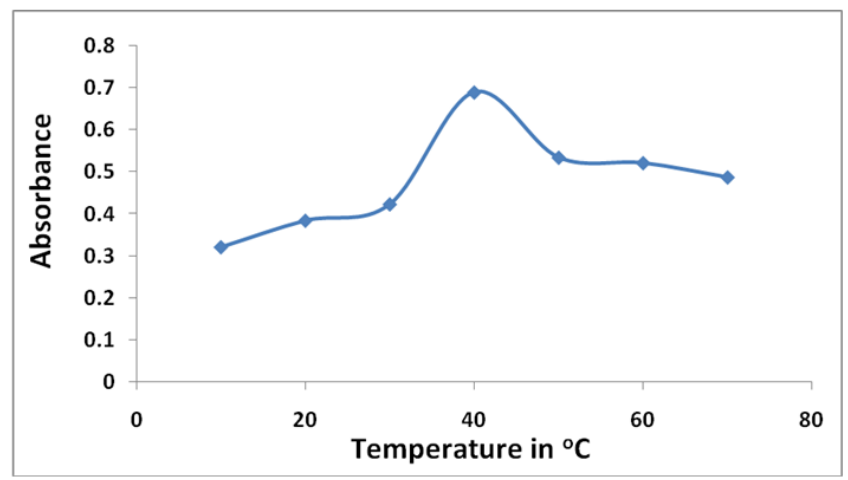

Figure 3 :Optimization of reaction temperature 
Suitable reaction temperature can reduce the activation energy and increase the rate of reaction. In this study optimization of reaction temperature has been done by performing same experimental procedure in different temperature. It has been observed that at $40^{\circ} \mathrm{C}$ intense colour developed. Hence this temperature has been taken for further analysis of different sample.

\section{Analytical Method Validation}

\section{Calibration curve and Linearity:}

For the proposed method the calibration curves were constructed by plotting the absorbance the final concentration of the drug. The corresponding regression equations were derived. From the calibration plot it has been found that the linearity of said method is between $0.04-0.4 \mu \mathrm{g} / \mathrm{ml}$. Results of linearity study reveals that the method follows Beer's Lambert law.

Further, limit of detection (LOD) and quantification (LOQ) of this method are $0.006 \mu \mathrm{g} / \mathrm{ml}$ and 0.018 $\mu \mathrm{g} / \mathrm{ml}$ respectively.

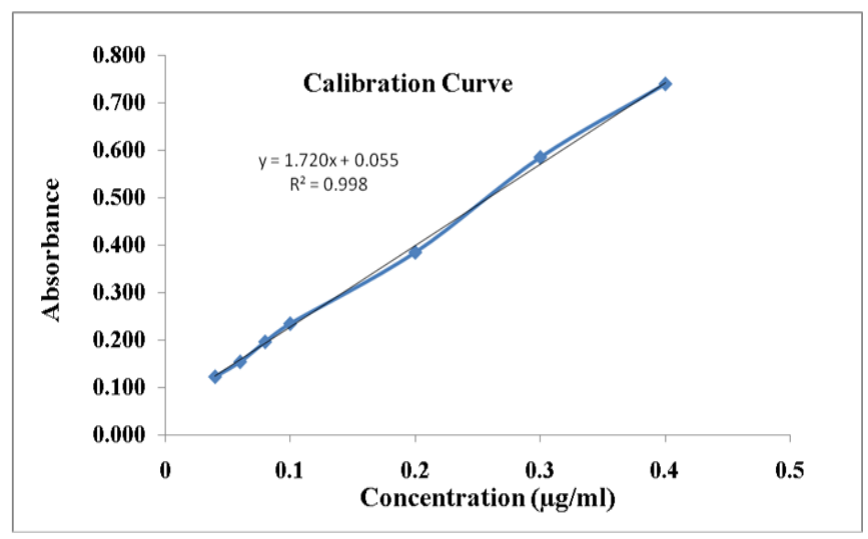

Figure 5 : Calibration curve of linearity

\section{Precision}

The precision study for proposed method was determined using intraday and interday analysis of three standards. From results it has been shown that the standard deviation and \% RSD of analysis was précised.

Table 1: Precision Study

\begin{tabular}{|l|l|l|l|}
\hline \multicolumn{4}{|c|}{ Intraday Precision Data n=3 } \\
\hline $\begin{array}{l}\text { Concentration } \\
(\mu \mathrm{g} / \mathrm{ml})\end{array}$ & $\begin{array}{l}\text { Average } \\
\text { Abs. }\end{array}$ & SD & \%RSD \\
\hline 0.06 & 0.109 & 0.002 & 1.40 \\
\hline 0.2 & 0.358 & 0.004 & 1.12 \\
\hline 0.4 & 0.741 & 0.008 & 1.09 \\
\hline \multicolumn{4}{|c|}{ Interday Precision Data n=3 } \\
\hline \begin{tabular}{l|l|l|l|} 
Concentration \\
$(\mu \mathrm{g} / \mathrm{ml})$
\end{tabular} & $\begin{array}{l}\text { Average } \\
\text { Abs. }\end{array}$ & SD & \%RSD \\
\hline 0.06 & 0.107 & 0.002 & 1.43 \\
\hline 0.2 & 0.362 & 0.005 & 1.27 \\
\hline 0.4 & 0.786 & 0.012 & 1.47 \\
\hline
\end{tabular}

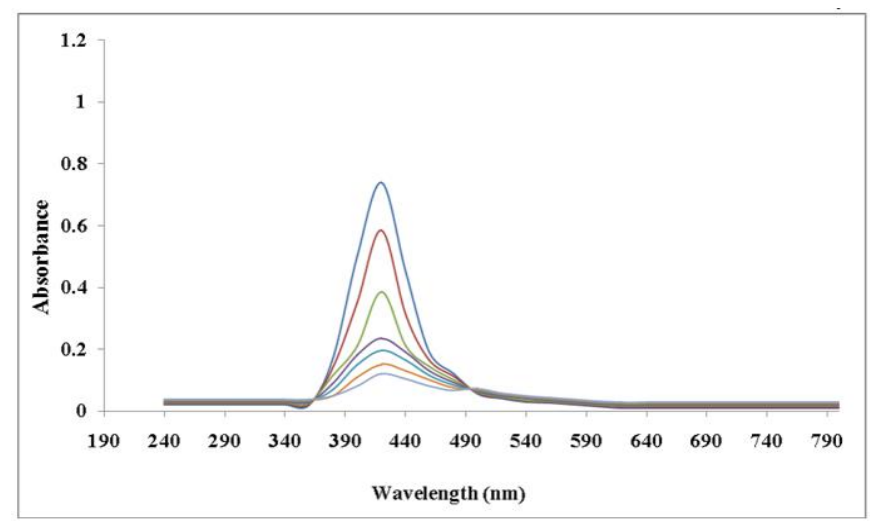

Figure 4 : UV spectra of linearity

\section{Accuracy}

The accuracy of the proposed method was evaluated by recovery study at different concentration levels $(80 \%, 100 \%, 120 \%)$. The result of this study indicates the good recovery of drug substance determination by proposed method. It also reveals that the proposed method is works in presence of interfering agents. 
Kartik B. Vyas et al. Int J Sci Res Sci Technol. May-June-2019; 6 (3) : 370-376 
Table 2 : Accuracy Study

\begin{tabular}{|c|c|c|c|c|}
\hline $\begin{array}{c}\text { Level of } \\
\text { Addition } \\
(\%)\end{array}$ & $\begin{array}{c}\text { Amount } \\
\text { Added } \\
(\mu \mathrm{g} / \mathrm{ml})\end{array}$ & $\begin{array}{c}\text { Total } \\
\text { Amount } \\
(\mu \mathrm{g} / \mathrm{ml})\end{array}$ & $\begin{array}{c}\text { Amount } \\
\text { Recover } \\
(\mu \mathrm{g} / \mathrm{ml})\end{array}$ & $\begin{array}{c}\% \\
\text { Recovery }\end{array}$ \\
\hline 80 & 0.160 & 0.200 & 0.195 & 97.50 \\
\hline 100 & 0.240 & 0.300 & 0.289 & 96.33 \\
\hline 120 & 0.320 & 0.400 & 0.387 & 96.75 \\
\hline Mean & \multicolumn{4}{|c|}{96.86} \\
\hline SD & \multicolumn{4}{|c|}{1.299} \\
\hline RSD & \multicolumn{4}{|c|}{1.342} \\
\hline
\end{tabular}

\begin{tabular}{|c|c|c|c|c|}
\hline 5 & 100 & 0.357 & 100.03 & 100.03 \\
\hline 6 & 100 & 0.360 & 100.08 & 100.08 \\
\hline 7 & 200 & 0.754 & 199.98 & 99.99 \\
\hline 8 & 200 & 0.761 & 200.64 & 100.32 \\
\hline Mean & \multicolumn{5}{|c|}{100.14} \\
\hline SD & \multicolumn{5}{|c|}{1.11} \\
\hline $\begin{array}{c}\text { \%RS } \\
\text { D }\end{array}$ & \multicolumn{5}{|c|}{} \\
\hline
\end{tabular}

\section{Chemistry of colour formation}

NBD made a stable colored complex with primary

\section{Assay of marketed formulation}

Here we take different Vimpat formulation for analysis in this study. We take on liquid formulation which has $10 \mathrm{mg} / \mathrm{ml}$ dosage and three oral formulations which have 50mg, $100 \mathrm{mg}$ and $200 \mathrm{mg}$ per tablet. The procedure to made sample solution as describe previously. The absorbance values of these solutions were recorded at $420 \mathrm{~nm}$ and it was shown in Table 3. A comparision of these values with those obtained from the standard LA was made and after applying the appropriate dilution factor, the amounts of LA present in each formulation was calculated.

Table 3: Assay of different formulation

\begin{tabular}{|c|l|l|l|l|}
\hline $\begin{array}{l}\text { Sr. } \\
\text { No }\end{array}$ & $\begin{array}{l}\text { Labe } \\
\mathbf{l} \\
\text { Clai } \\
\mathrm{m} \\
(\mathrm{mg})\end{array}$ & $\begin{array}{l}\text { Absorbance } \\
\text { value } \\
\text { at } 420 \mathrm{~nm}\end{array}$ & $\begin{array}{l}\text { Amount } \\
\text { of } \\
\text { LA } \\
\text { found }\end{array}$ & $\begin{array}{l}\text { Percentag } \\
\text { e } \\
\text { assay (\%) }\end{array}$ \\
\hline 1 & 10 & 0.074 & 10.02 & 100.2 \\
\hline 2 & 10 & 0.078 & 10.08 & 100.8 \\
\hline 3 & 50 & 0.196 & 50.01 & 100.02 \\
\hline 4 & 50 & 0.194 & 49.82 & 99.64 \\
\hline
\end{tabular}
and secondary amines [17]. LA has two secondary amino groups in its structure hence after the derivatization of these secondary amino groups of drug molecule made a stable condensation product with NBD solution. This reaction is $\mathrm{pH}$ sensitive hence it could be only takes place in the presence of phosphate buffer $\mathrm{pH}$ 7.2. The colored complex has a characteristic adsorption spectrum with maximum adsorption at $420 \mathrm{~nm}$. The proposed reaction scheme is presented in (Fig.6).

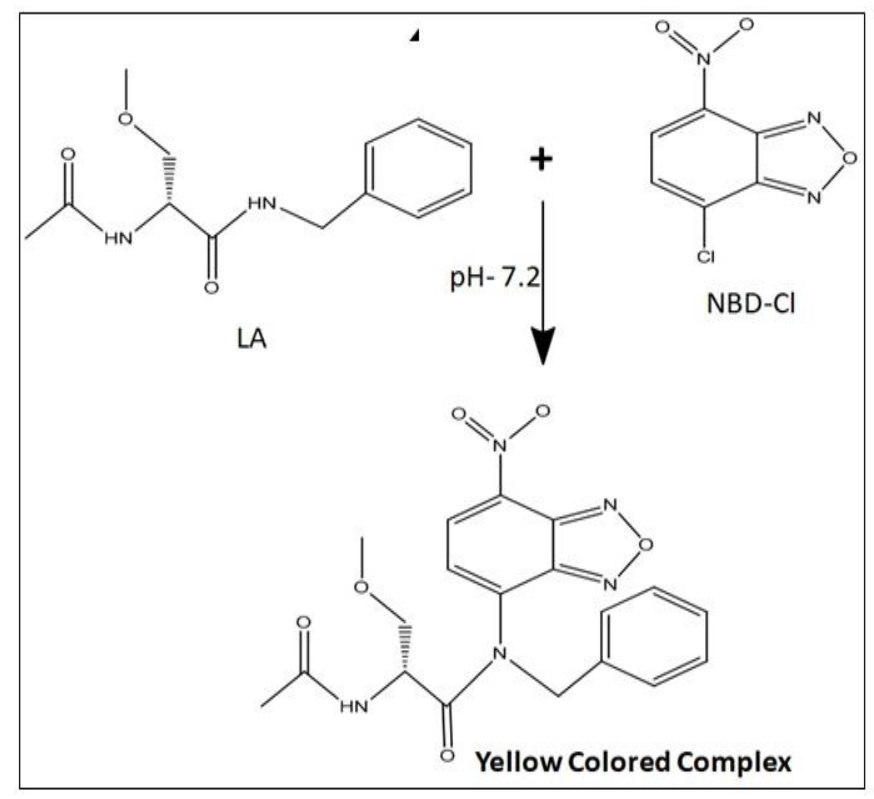

Figure 6 : Mechanism of colour development 


\section{CONCLUSION}

The present study reported successful development and evaluation of 4-Chloro-7-nitrobenzo-2-oxa-1,3diazole assisted detection method of Lacosamide. The developed method selectively and sensitively deter mines lacosamide in bulk drug and its different formulations. Different validation study such as precision, accuracy, linearity study reveals that the developed method is fully validate as per ICH guidelines. The developed method does not need any expensive sophisticated equipment. The colored complex produce in this method is stable it shows high throughput property of this method. Hence, this method is commercially viable and valuable for its routine application in quality control laboratories for analysis of lacosamide.

\section{REFERENCES}

[1]. P. Kwan,M. J. Brodie. Early identification of refractory epilepsy. N Engl J Med. (2000). 342:314-319.

[2]. S. Cortes, Z. K. Liao, D. Watson, H. Kohn. 1985. J Med Chem.(1985). 28:601-606.

[3]. B. K. Beyreuther, J. Freitag, C. Heers, et al. CNS Drug Rev.Lacosamide: a review of preclinical properties. (2007). 13:21-42.

[4]. D.Choi, J. P. Stables, H. Kohn.J Med Chem. (1996). 39:1907-1916.

[5]. W. Cawello. Clin Pharmacokinet (2015). 54(9):901-14.

[6]. G. A. McMillin,M. D.Krasowski.. Cambridge, MA: Elsevier, 2016;101-34.

[7]. I. Malissin, F. J. Baud, M. Deveaux,S. Champion,N. Deye, B. Megarbane.Clin Toxicol. (2013). 51(4):381-2.

[8]. W. Cawello, B. Rosenkranz, B. Schmid, W. Wierich.Epilepsia (2013). 54(3):530-6.
[9]. C. Kestelyn, M. Lastelle, N. Higuet, S. Dell'Aiera, L. Staelens, P. Boulanger, et al.Bioanalysis (2011). 3(22):2515-22.

[10]. J. Gonc_alves, G. Alves, J. Bicker, A. Falc ${ }^{\sim}$ ao, A. Fortuna.Bioanalysis ( 2018). 10(8):541-57.

[11]. D. Payto, N. Foldvary-Schaefer,N. So, M. Bruton, S. Wang.Bioanalysis (2014). 6(23):1618.

[12]. J. Kuhn, C.Knabbe.Talanta (2013). 110:71-80.

[13]. P. Nikolaou, I.Papoutsis, C. Spiliopoulou,C. Voudris, . J Sep Sci (2015). 38(2):260-6.

[14]. M. A. Korany, H. Mahgoub, R. S.Haggag, M. A. Ragab, O. A. Elmallah.J Chromatogr B( 2018).1083:75-85

[15]. Atul Ajay Moghe, Thesis entitled Development of modern analytical methods in drug analysis, chapter 2, UV-VIS Spectroscopic determination of Rosiglitazone., (2002).

[16]. ICH topics Q 2 A, validation of Analytical methods: Definitions and terminology, Geneva (1996).

[17]. Seshamamba BSV, Sekaran CB, Glob Drugs Therap, 2017; 2: 1-8

\section{Cite this article as :}

Vikramsinh R. Chauhan, Deepshikha Sharma, Kartik B. Vyas, "Spectrophotometric Determination of Lacosamide in Bulk Drug and Oral Dosage Formulation ", International Journal of Scientific Research in Science and Technology (IJSRST), Online ISSN : 2395-602X, Print ISSN : 2395-6011, Volume 6 Issue 3, pp. 370-376, May-June 2019. Available at doi : https://doi.org/10.32628/IJSRST207262 Journal URL : http://ijsrst.com/IJSRST207262 